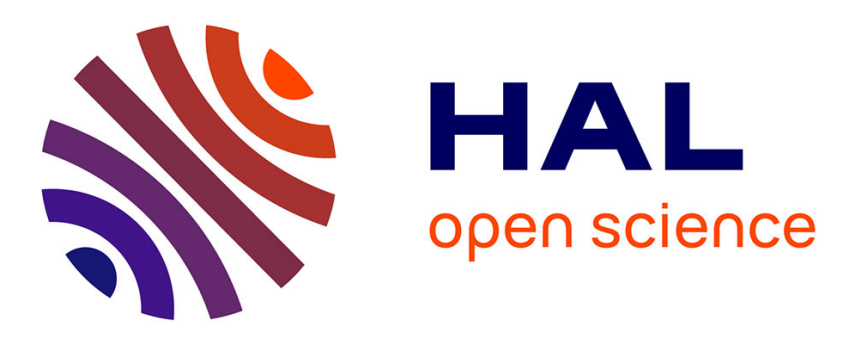

\title{
Modelling CO 2 transfer in foil ripened semi-hard Swiss-type cheese
}

F. Acerbi, Valérie V. Guillard, M. Saubanère, C. Guillaume, Nathalie Gontard

\section{To cite this version:}

F. Acerbi, Valérie V. Guillard, M. Saubanère, C. Guillaume, Nathalie Gontard. Modelling CO 2 transfer in foil ripened semi-hard Swiss-type cheese. Journal of Food Engineering, 2018, 222, pp.73 83. 10.1016/j.jfoodeng.2017.10.025 . hal-01645481

\section{HAL Id: hal-01645481 https://hal.science/hal-01645481}

Submitted on 26 May 2020

HAL is a multi-disciplinary open access archive for the deposit and dissemination of scientific research documents, whether they are published or not. The documents may come from teaching and research institutions in France or abroad, or from public or private research centers.
L'archive ouverte pluridisciplinaire HAL, est destinée au dépôt et à la diffusion de documents scientifiques de niveau recherche, publiés ou non, émanant des établissements d'enseignement et de recherche français ou étrangers, des laboratoires publics ou privés.

\section{(c)(1)}

Distributed under a Creative Commons Attribution| 4.0 International License 


\section{Accepted Manuscript}

Modelling $\mathrm{CO}_{2}$ transfer in foil ripened semi-hard Swiss-type cheese

F. Acerbi, V. Guillard, M. Saubanere, C. Guillaume, N. Gontard

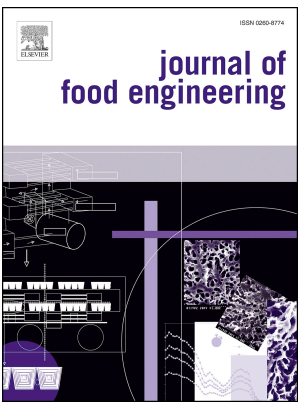

PII:

S0260-8774(17)30458-2

DOI: $\quad$ 10.1016/j.jfoodeng.2017.10.025

Reference: JFOE 9058

To appear in: Journal of Food Engineering

Received Date: 30 May 2017

Revised Date: 27 October 2017

Accepted Date: 28 October 2017

Please cite this article as: Acerbi, F., Guillard, V., Saubanere, M., Guillaume, C., Gontard, N., Modelling $\mathrm{CO}_{2}$ transfer in foil ripened semi-hard Swiss-type cheese, Journal of Food Engineering (2017), doi:

10.1016/j.jfoodeng.2017.10.025.

This is a PDF file of an unedited manuscript that has been accepted for publication. As a service to our customers we are providing this early version of the manuscript. The manuscript will undergo copyediting, typesetting, and review of the resulting proof before it is published in its final form. Please note that during the production process errors may be discovered which could affect the content, and all legal disclaimers that apply to the journal pertain. 
Journal of Food Engineering

2 Modelling $\mathrm{CO}_{2}$ transfer in foil ripened semi-hard Swiss-type cheese

$5 \quad{ }^{a}$ UMR 1208 IATE Agro-polymer Engineering and Emerging Technologies, Montpellier (France),

6 University of Montpellier, INRA - 2 place Viala - bât. 31, F-34060 Montpellier Cedex 01

$7 \quad{ }^{b}$ UMR 5253 - Institut Charles Gerhardt, Montpellier (France), Place Eugène Bataillon, 34090 Montpellier

$8 *$ corresponding author: valerie.guillard@umontpellier.fr

9 
Journal of Food Engineering

3

Abstract

Eye growth in cheese with intense $\mathrm{CO}_{2}$ production during ripening mainly depends on $\mathrm{CO}_{2}$ production and transfer properties. - Despite $\mathrm{CO}_{2}$ production and diffusion during ripening of semi-hard Swiss-type cheese eyes in such cheeses are considered as important quality parameters, the research concerning key gas production and transfer in cheese remains widely overlooked. In this study, experimentally assessed $\mathrm{CO}_{2}$ production was coupled with transfer coefficients in a mathematical model in order to predict $\mathrm{CO}_{2}$ gradients formed inside the cheese during ripening. The permeability coefficient of $\mathrm{CO}_{2}$ through the multilayer barrier packaging which wraps the cheese during ripening was also included in the model. The presented model was validated by assessing the $\mathrm{CO}_{2}$ concentration in the cheese and its partial pressure in the packaging headspace. $\mathrm{CO}_{2}$ production rate was found to be the most important input parameter affecting $\mathrm{CO}_{2}$ gradients formed in cheese during ripening whereas the other input parameters (solubility, diffusivity, permeability) had little effect on the total $\mathrm{CO}_{2}$ gradient. Keywords: solubility, diffusivity, permeability, $\mathrm{CO}_{2}$, cheese ripening 
Journal of Food Engineering

\section{Nomenclature}

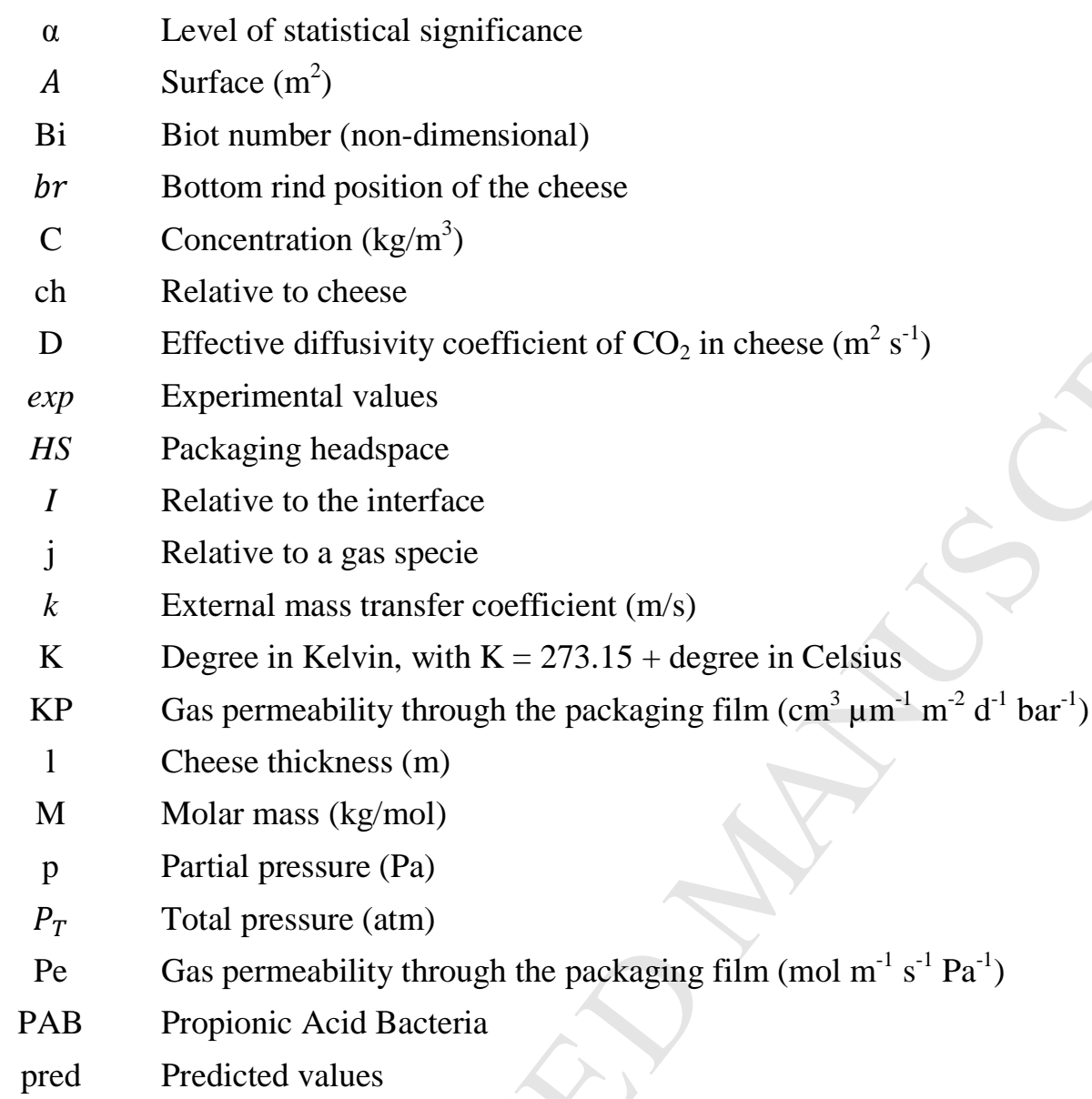

PTATN ratio of phosphotungstic acid soluble nitrogen on total nitrogen $(\mathrm{g} / 100 \mathrm{~g})$

$\mathrm{S}$ or SCO2 Solubility coefficient of $\mathrm{CO}_{2}$ in cheese $\left(\mathrm{mol} \mathrm{m}^{-3} \mathrm{~Pa}^{-1}\right.$ or $\left.\mathrm{mmol} \mathrm{kg}{ }^{-1} \mathrm{~atm}^{-1}\right)$ or $\mathrm{CO}_{2}$ solubility

SM Salt in moisture ratio $(\mathrm{g} / 100 \mathrm{~g})$

$\mathrm{t} \quad$ Time (s)

T Temperature (K)

$\mathrm{R} \quad$ Universal gas constant: $8.314\left(\mathrm{~J} \mathrm{~mol}^{-1} \mathrm{~K}^{-1}\right)$

CVRMSD Coefficient of variation of the root mean squared deviation

$\mathrm{V} \quad$ Volume $\left(\mathrm{m}^{3}\right)$

$\mathrm{x} \quad$ Position in the cheese (m)

y Experimental or predicted variable

$\mu \quad$ average

$\boldsymbol{\varphi} \quad$ Mass flow $\left(\mathrm{kg} \mathrm{s}^{-1}\right)$

$v \quad$ Production rate $\left(\mathrm{kg} \mathrm{m}^{-3} \mathrm{~s}^{-1}\right)$

$\infty \quad$ Relative to the surrounding atmosphere 
Journal of Food Engineering

26 


\section{ACCEPTED MANUSCRIPT}

\section{Journal of Food Engineering}

\section{Introduction}

In food engineering, mathematical modelling of physical mechanisms such as heat or mass transfer was used for many years to simulate and optimize/control operation units such as drying or salting (Bona et al., 2007; Mayor and Sereno, 2004; Payne and Morison, 1999; Santapaola et al., 2013). More recently these models were coupled to biological ones such as Mickaëlis Menten equation that formalize the aerobic respiration (Ho et al., 2011; Guillard et al., 2012), chemical reaction for oxidation (Bacigalupi et al., 2013) or predictive microbiology models in order to better represent the evolution of the packed food during storage (Chaix et al., 2015).

This modelling approach coupling equations coming from different disciplinary fields was recently applied to semi-hard Swiss-type cheese in order to model the eyes' growth during ripening (Laridon, 2014; Laridon et al., 2016). $\mathrm{CO}_{2}$-source in this type of cheese is propionic acid bacteria $(\mathrm{PAB})$ which means that $\mathrm{CO} 2$-production rate and amount in such cheese is much higher compared to that of lactic acid bacteria. The ripening of these cheeses includes a step during which cheeses are stored at warm temperature (about $1-2$ weeks at $20-25^{\circ} \mathrm{C}$ ) for stimulating the PAB fermentation. During this step, $\mathrm{CO}_{2}$ is intensively produced, leading to the growth of eyes (Fröhlich-Wyder and Bachmann, 2004). Cheeses are often foil ripened and a plastic packaging is used to wrap the cheeses during the whole ripening period for avoiding excessive loss of gaseous compounds. The modelling approach proposed by Laridon (2014) therefore concomitantly took into account mass transfer of gas $\left(\mathrm{CO}_{2}\right.$ produced by bacteria and responsible of eyes' growth), production of the $\mathrm{CO}_{2}$ and mechanical constraint imposed to cheese paste by this production. This model was based on experimentally assessed rheological parameters (stress) and $\mathrm{CO}_{2}$ production rate in simplified condition, but some input parameters such as $\mathrm{CO}_{2}$ diffusivity and solubility into the cheese were estimated from the literature and assumed constant throughout the cheese paste and the ripening age. The sensitivity analysis performed by these authors revealed 


\section{Journal of Food Engineering}

51 afterwards the higher influence of $\mathrm{CO}_{2}$ production and diffusion parameters compared to the

52 rheological ones in semi-hard cheese (Laridon, 2014).

53 Faced to the importance of $\mathrm{CO}_{2}$ diffusion and $\mathrm{CO}_{2}$ production rate in the ripening of semi-hard

54 Swiss-type cheese, this paper aimed at deepening these two phenomena by coupling them in a mathematical model in order to simulate and predict evolution with time of $\mathrm{CO}_{2}$ gradients in the cheese paste and in the packed cheese (including $\mathrm{CO}_{2}$ permeation through the ripening foil). In this purpose, the aim of this study was to develop and experimentally validate in various conditions, mimicking the ripening conditions of Swiss-type cheese, a mathematical diffusionreaction model to predict $\mathrm{CO}_{2}$ gradients in packed cheeses during ripening.

\section{Materials and methods}

\subsection{Cheese and packaging}

Semi-hard cheese blocks of $1 \mathrm{~kg}$ were kindly supplied by a cheese company. The cheeses included about $42 \% \mathrm{w} / \mathrm{w}$ moisture and $26.5 \% \mathrm{w} / \mathrm{w}$ fat, with $\mathrm{pH}$ varying from 5.50 to 5.70 from 14 to 28 days from renneting. The cheeses used for the model validation without $\mathrm{CO}_{2}$ production (same batch) did not include any intentionally added $\mathrm{CO}_{2}$ producing bacteria (PAB and heterofermentative lactic acid bacteria or LAB) and was produced from pasteurized milk to avoid any sources of hetero-fermentative $\mathrm{LAB}$ or $\mathrm{PAB}$. The cheeses used for the validation with $\mathrm{CO}_{2}$ production included PAB $\left(10^{6} \mathrm{CFU} \mathrm{m}{ }^{-1}\right.$ cheese milk) as main source of $\mathrm{CO}_{2}$ production. They were produced from a second, dedicated batch from pasteurized milk. After brining, all cheeses were packed in a multilayer barrier packaging film made of PE/PVDC/PE. Indicatively, the permeability to $\mathrm{CO}_{2}$ at $19^{\circ} \mathrm{C}$ equalled $40000 \mathrm{~cm}^{3} \mu \mathrm{m} \mathrm{m}^{-2} \mathrm{~d}^{-1}$ bar $^{-1}$ (Acerbi et al., 2016c). The ripening schedule of all ripened cheeses was as follows: $13^{\circ} \mathrm{C}$ until 14 days from renneting, $19^{\circ} \mathrm{C}$ 
Journal of Food Engineering

74 for 14 days, $2-3$ days at $13^{\circ} \mathrm{C}$, longer storage at $6^{\circ} \mathrm{C}$. The target chemical composition of cheeses

75 used in this study is described in Table 1.

76 Cheese blocks were about 15 to $8 \mathrm{~cm}$ square in shape (see Supplementary Material A) and were 77 sampled in their core, orthogonally to the interface exposed to headspace/surrounding atmosphere

78 (Figure 1), at least $3 \mathrm{~cm}$ away from side rinds, resulting in a cylinder of $8 \mathrm{~cm}$ height and about 2 $\mathrm{cm}$ of diameter. The sampling region was then cut in thin slices of minimum $0.5 \mathrm{~cm}$ of thickness for assessment of chemical composition gradient or $\mathrm{CO}_{2}$ gradient.

\section{Table 1}

\subsection{Chemical analyses}

The chemical composition (fat, moisture, $\mathrm{pH}$, total nitrogen (TN) and fractions of TN, salt, organic acids) of three cheeses per production was measured, in order to verify that the cheese production was on target. Dry matter and sodium chloride were measured according to the ISO 5534 (Anonymous, 2004a) and ISO 5943 (Anonymous, 2006) standards. Total nitrogen (TN), water soluble nitrogen $(\mathrm{SN})$ and phosphotungstic acid soluble nitrogen (PTA-N) were measured using Kjeldahl based methods according to ISO 8968-3 standard (Anonymous, 2004b; Bütikofer et al., 1993). The ratio of PTA-N on TN (g/100g) was considered as a good proteolytic indicator. $\mathrm{pH}$ and fat content were characterized according to respectively, FD V04-035 (Anonymous, 2009) and NF V04-287 (Anonymous, 2002) French standards. Organics acids were assayed using internal method based on high-performance liquid chromatography.

$\mathrm{CO}_{2}$ determination in cheese was carried out with the protocol described in Acerbi et al. (2016b). The protocol included a first step where $\mathrm{CO}_{2}$ was extracted from the cheese sample by immersing it in acidic solution. The extracted $\mathrm{CO}_{2}$ was then scavenged by a soda solution of known 
Journal of Food Engineering

98

molarity, which was finally titrated with hydrochloric acid. The difference between the initial and final soda molarity related to the moles which reacted with $\mathrm{CO}_{2}$.

\subsection{Microbiology analyses}

Propionic acid bacteria were enumerated with a method based on the count of the diluted colonies grown on agar plates enriched mainly with sodium lactate and yeast extract after 1 week of incubation at $30^{\circ} \mathrm{C}$. The results were expressed in colony-forming unit per gram of cheese (CFU $\left.\mathrm{g}^{-1}\right)$

\subsection{Gas chromatography for headspace analyses}

The partial pressure of $\mathrm{N}_{2}, \mathrm{O}_{2}$ and $\mathrm{CO}_{2}$ was measured (resolution: $0.005 \%$ ) by injecting $10 \mu \mathrm{l}$ of headspace of cheese packs inside a micro gas chromatography unit including a thermal conductivity detector (MicroGC 3000, SRA Instruments). Homogeneity of the gas composition was ensured by pumping few millilitres of sample gas inside the micro gas chromatography unit before each measurement. The cheese packs were not kept after the analyses because of the too low amount of headspace volume. Therefore, new cheese packs produced from the same batch were used for each analysis in order to follow the kinetics of headspace composition during ripening. The gas chromatography unit was previously calibrated with gas bottles of known compositions. At least two measurements were carried out per each sample.

\subsection{Description of the model}

Evolution of $\mathrm{CO}_{2}$ partial pressures in the foil packed blind cheese during ripening relies on the interplay of four mechanisms: (1) $\mathrm{CO}_{2}$ production due to the activity of microorganisms (PAB), (2) gas transport within the cheese paste, (3) gas transfer at the cheese rind/headspace interface and (4) gas transmission through the packaging film. The four described mechanisms are illustrated in figure 1. 
Journal of Food Engineering

\section{Figure 1}

\subsubsection{Model assumptions}

125 The following assumptions were made in the present mono-directional modelling study:

- The composition of the atmosphere surrounding the packed cheese during ripening is constant and equals to $78.1 \%$ for $\mathrm{N}_{2}, 20.9 \%$ for $\mathrm{O}_{2}$ and $0.03 \%$ for $\mathrm{CO}_{2}$ (Widory and Javoy, 2003).

- Temperature in the packed cheese system and surrounding atmosphere is constant, without gradients.

- Total pressure of the system is constant and it equals atmospheric pressure (101325 Pa).

- The solubilization of $\mathrm{N}_{2}$ inside the cheese was considered negligible compared to $\mathrm{CO}_{2}$, because of its lower solubility in water (about 50 times less soluble than $\mathrm{CO}_{2}$ in water at $20^{\circ} \mathrm{C}$ ) (Dean, 1999). $\mathrm{O}_{2}$ solubility and diffusivity in the cheese were set to constant values of $2.510^{-9} \mathrm{~m}^{2} \mathrm{~s}^{-1}$ and $1.3 \mathrm{mmol} \mathrm{kg}^{-1} \mathrm{~atm}^{-1}$ respectively and which correspond to solubility and diffusivity of the gas in water at $20^{\circ} \mathrm{C}$ (Chaix et al., 2014).

- The mechanical resistance to deformation of the cheese packaging is not taken into account in the model. Thus, volume changes according to moles content inside the pack and total pressure of headspace remains equal to external atmospheric pressure. Measuring volume changes during experiment has revealed that they are negligible and that the flexible pouch could easily compensate the small volume change due to its property of elongation. 
Journal of Food Engineering

- For the cheese with salt gradient, the initial $\mathrm{NaCl}$ gradient was measured in cheeses produced within the same production day and it was considered to remain constant during the experiment. Same assumption was used to quantify the proteolytic indicator (PTATN).

- Gradients in chemical composition in the cheese from its upper rind to its core are symmetric to the gradients from lower rind to the core.

\subsubsection{Gas balance in headspace}

The variation of concentration of the gas species $j$ in the packaging headspace $H S$ depends on the mass flow of gas permeating the packaging film $f$ from the surrounding atmosphere $\varphi_{j_{f}}(\mathrm{~kg} / \mathrm{s})$ and the mass flow of the gas species occurring at the interface between the cheese and the headspace $\varphi_{j_{I}}$.

Assuming that the packaging film does not oppose any mechanical resistance to deformation, when the amount of gas species in the headspace varies, the headspace volume $V_{H S}\left(\mathrm{~m}^{3}\right)$ changes, whereas the total pressure in the headspace $P_{T}$ remains constant and equal to atmospheric pressure $(101325 \mathrm{~Pa})$. The global mass balance of species $j$ in the headspace can hence be written as follows:

$$
V_{H S} \frac{d C_{j_{H S}}}{d_{t}}+C_{j_{H S}} \frac{d V_{H S}}{d_{t}}=\varphi_{j_{f}}+\varphi_{j_{I}}
$$

where $C_{j_{H S}}\left(\mathrm{~kg} / \mathrm{m}^{3}\right)$ is the concentration of the gas in the headspace and $t$ is time (s).

Assuming that the gas mixture in the headspace obeys the ideal gas law, $\frac{d V_{H S}}{d_{t}}$ can be calculated as a pondered sum of the different aforementioned mass flow $\varphi_{j_{f}}, \varphi_{j_{I}}$ as follows:

$$
\frac{d V_{H S}}{d_{t}}=\frac{R T}{P_{T}}\left(\frac{\varphi_{\mathrm{CO}_{f}+} \varphi_{\mathrm{CO}_{2}}}{M_{\mathrm{CO} 2}}+\frac{\varphi_{O 2_{f}}+\varphi_{O 2_{I}}}{M_{O 2}}+\frac{\varphi_{N 2_{f}}}{M_{N 2}}\right)
$$




\section{Journal of Food Engineering}

164

165

166

167

168

169

170

171

172

173

174

175

176

177

178

179

180

181

182

183

184

185

where $M_{j}$ is the gas molar mass $(\mathrm{kg} / \mathrm{mol}), \mathrm{R}$ the universal gas constant $\left(\mathrm{J}\right.$ mol$\left.^{-1} \mathrm{~K}^{-1}\right)$ and $\mathrm{T}$ the temperature in Kelvin (K).

The concentration of the gas in the headspace $C_{j_{H S}}$ can be calculated according to (Eq. 3)

$$
R T \sum_{j=\left\{O_{2}, \mathrm{CO}_{2}, \mathrm{~N}_{2}\right\}} \frac{C_{j, H S}}{M_{j}}=P_{T}=10^{5} \mathrm{~Pa}
$$

and similarly, for the partial pressure of the gas in the headspace $p_{j_{H S}}$ (Eq. 4),

$$
p_{j_{H S}}=\frac{C_{j_{H S}} R T}{M_{j}}
$$

\subsubsection{Gas permeation through the maturation foil}

The gas permeation through the packaging film (maturation foil), assuming that the partial pressures in the atmosphere surrounding the cheese are constant, could be conveniently described by the Fick's first law (steady state regime). Therefore, the mass flow $\varphi_{f}$ of gases $\mathrm{j}\left(\mathrm{N}_{2}, \mathrm{O}_{2}, \mathrm{CO}_{2}\right)$ through the packaging film was calculated according to first Fick's law (Fick, 1855) as stated in Eq. 5.

$$
\varphi_{j_{f}}=M_{j} P e_{j} \frac{A_{f}}{l_{f}}\left(p_{j_{\infty}}-p_{j_{H S}}\right)
$$

where $P e_{j}$ is the permeability coefficient of the gas $\mathrm{j}$ through the film (mol m $\left.\mathrm{m}^{-1} \mathrm{~s}^{-1} \mathrm{~Pa}^{-1}\right), l_{f}$ is the thickness of the film (m), $A_{f}$ is the film surface $\left(\mathrm{m}^{2}\right)$ and $p_{j_{\infty}}$ and $p_{j_{H S}}$ are the partial pressure of the gas $j$ in the surrounding atmosphere (denoted by symbol $\infty$ ) and the packaging headspace, denoted by $H S$.

\subsubsection{Mass flow at the cheese rind/gaseous interface}

The mass flow at the cheese/rind gaseous interface was calculated as follows (Eq. 6):

$$
\varphi_{j_{I}}=k j\left(\frac{M_{j} A_{I}}{R T}\right)\left(p_{j_{H S, I}}-p_{j_{H S}}\right)
$$

Where $k(\mathrm{~m} / \mathrm{s})$ is the mass transfer coefficient at the interface between the cheese rind and the headspace and $A_{I}$ and $p_{j_{H S, I}}$ are the surface at the interface and the partial pressure at the 


\section{Journal of Food Engineering}

186

187

188

189

190

191

192

193

194

195

196

197

198

199

200

201

202

203

204

205

206

immediate vicinity of the cheese surface. The mass transfer coefficient $k$ is calculated according to Eq. 7

$$
k j=\frac{B i \times D_{j}}{L}
$$

Where $B i$ is the non-dimensional Biot number, assumed to be equal to $10^{5}$ (ratio between diffusivity of $\mathrm{CO}_{2}$ in air and cheese) (Laridon, 2014), $D_{j}$ is the diffusivity of $\mathrm{CO}_{2}$ in cheese (about $10^{-10} \mathrm{~m}^{2} \mathrm{~s}^{-1}$ ) and $\mathrm{L}$ is the characteristic length of the considered material (length of the cheese equalled about $0.008 \mathrm{~m})$.

Assuming that the gaseous species in headspace are in thermodynamic equilibrium with the dissolved species at the cheese surface, the concentration of dissolved gas species $j$ at the cheese surface $C_{j_{c h, x=0}}\left(\mathrm{~kg} / \mathrm{m}^{3}\right)$ relates to $p_{j_{H S, I}}$ according to Henry's law:

$$
p_{j_{H S, I}}=\frac{C_{j_{c h, x=0}}}{M_{j} S_{j}}
$$

Where $S_{j}$ is the solubility coefficient of the considered gas $j\left(\mathrm{~mol} \mathrm{~m}^{-3} \mathrm{~Pa}^{-1}\right)$.

\subsubsection{Gas diffusion inside the cheese paste and $\mathrm{CO}_{2}$ production}

The $\mathrm{CO}_{2}$ diffusion within the cheese paste was represented by making use of Fick's second law of diffusion for the transient state of diffusion and it was coupled to $\mathrm{CO}_{2}$ production by adding production term $v\left(\mathrm{~kg} \mathrm{~m}^{-3} \mathrm{~s}^{-1}\right)$ to Fick's second law, leading to Eq. 9.

$$
\frac{{ }^{{ }^{C} C_{C O 2} c h}}{\partial t}=D_{C O 2} \frac{\partial^{2}{ } C_{C O 2} c h}{\partial x^{2}}+v_{C O 2}
$$

Where $\frac{{ }_{C_{C O}} c h}{\partial t}$ is the partial derivative of the concentration of $\mathrm{CO}_{2}$ in the cheese as regard to time, in the direction $x(\mathrm{~m}) . x$ represents the distance from the interface of the cheese rind to headspace and the considered position inside the cheese. $x$ varies from 0 to 8 (cheese thickness in $\mathrm{cm}$ ). $D_{\mathrm{CO} 2}$ is the effective diffusivity coefficient of $\mathrm{CO}_{2}$ in cheese $\left(\mathrm{m}^{2} / \mathrm{s}\right)$. 
Journal of Food Engineering

207 The same equation without the production term was used to model $\mathrm{O}_{2}$ diffusion within the cheese 208 paste.

209

210

211

212

213

214

215

216

217

\subsubsection{Boundary conditions}

Equality of flows was considered at the interface between the cheese rind and the headspace:

$$
D_{j} \frac{\partial_{C_{j_{c h}}}}{\partial x}=\frac{\varphi_{j_{I}}}{A_{I}}=k j\left(\frac{M_{j}}{R T}\right)\left(p_{j_{H S, I}}-p_{\left.j_{H S}\right)} \text { at } x=0\right.
$$

where $j$ stands for either $\mathrm{CO}_{2}$ or $\mathrm{O}_{2}$.

Since the cheese is pressed on continuous impermeable material during ripening due to gravity, we assumed no diffusion at the cheese bottom rind $(b r),(x=b r)$ :

$$
D_{j} \frac{\partial_{C_{j} h}}{\partial x}=0 \text { at } x=b r
$$

Assuming that the food sample was initially in equilibrium with a gas of fixed partial pressure $p_{j_{0}}$ $(\mathrm{Pa})$, the initial conditions take the form:

$$
C_{j_{c h}}(x, 0)=M_{j} S j p_{j_{0}}(x, 0) \text { for } t=0
$$

\subsubsection{Prediction of model input parameters for different ripening conditions}

The following empirical equation was used in the model for predicting the changes in $\mathrm{CO}_{2}$ production rate, $v_{\mathrm{CO} 2}\left(\mathrm{mmol} \mathrm{kg}^{-1} \mathrm{~d}^{-1}\right)$ as a function of salt to moisture ratio, SM and temperature, T (Acerbi et al., 2016a):

$$
v_{C O 2}=8.527+0.0862 \mathrm{~T}^{2}-1.621 \mathrm{~T}+5.367 \mathrm{SM}-0.415 \mathrm{SM} \mathrm{T}
$$

SM $(\mathrm{g} / 100 \mathrm{~g})$ is calculated as the percentage of the mass ratio between sodium chloride and moisture.

The following empirical equation was used in the model for predicting the value of $D_{\mathrm{CO} 2}$ at different temperatures, $T$ salt to moisture ratio, SM and PTATN (ratio of phosphotungstic acid soluble nitrogen on total nitrogen). The latter coefficient is a ripening indicator related to the 
Journal of Food Engineering

229 proteolytic phenomena (especially amount of free amino acids) which relates to structure changes

230 in the cheese during ripening (Acerbi et al., 2016d).

231

$$
D_{C O 2}=\left(-0.0428 \mathrm{~T}^{2}+1.3689 \mathrm{~T}-0.6188 \mathrm{SM}+12.2421 \text { PTATN }-9.6910\right) \times 10^{-10}
$$

233 The value of $S_{\mathrm{CO} 2}$ (in $\mathrm{mmol} \mathrm{kg}^{-1} \mathrm{~atm}^{-1}$ ) was calculated by using a modified version of the equation given by Acerbi et al. (2016b):

$$
S_{C O 2}=37.35879-0.83414 S M^{2}+4.4619 S M-0.34768 T
$$
the gas transfer and permeation in the cheese packaging headspace was solved using a dedicated

\section{Figure 2}

The value of permeability $(K P)$ of the gas $j\left(\mathrm{O}_{2} \mathrm{CO}_{2}, \mathrm{~N}_{2}\right)$ was estimated at different ripening temperatures by interpolating the results of permeability coefficients $K P$ given by Acerbi et al. (2016c) in units $\mathrm{cm}^{3} \mu \mathrm{m} \mathrm{m}^{-2} \mathrm{~d}^{-1} \mathrm{bar}^{-1}$. The $K P$ values were converted into $P e$ values ( $\mathrm{mol} \mathrm{m}^{-1} \mathrm{~s}^{-1}$ $\mathrm{Pa}^{-1}$ ) to be used in the model (Eq. 5).

$$
K P_{\mathrm{CO} 2}=-108.03 T^{2}+4551.5 T-3242.6
$$

$$
K P_{O 2}=386.53 T+6313.6
$$

$$
K P_{N 2}=188.78 T+3422
$$

\subsubsection{Numerical solving and identification procedure}

This system of equations governing the coupled diffusion and production of gas in the cheese and algorithm "ode15s" developed in Matlab® computing software (The Mathworks Inc., Natick, 
Journal of Food Engineering

252 Mass, USA) and adapted to stiff systems where each of unknown variables may exhibit radically

253 different variation kinetics. This algorithm adjusted automatically the size of the time step used

254 for numerical integration of the equations. To evaluate goodness of fit between experimental and

255 predicted data, the coefficient of variation of the root mean square deviation (CVRMSD) was

256 calculated as follows:

$$
C V R M S D=\left(\frac{\sqrt{\frac{(y p r e d-y e x p)^{2}}{(N)}}}{\mu_{e x p}}\right) \times 100
$$

Where $\mathrm{y}_{\text {pred }}$ and $\mathrm{y}_{\exp }$ are respectively the experimental and the simulated residual value, $\mathrm{N}$ is the number of experimental measurements and $\mu_{\text {exp }}$ is the average of the experimental values. CVRMSD enables to compare the quality of the model with other models present in literature. A good quantitative model is considered to have CVRSMD $\leq 10 \%$.

\subsection{Model validation}

The experimental validation was made in three steps of increasing complexity which are summarized in Table 1.

- Firstly, the mono-directional $\mathrm{CO}_{2}$ diffusion within the cheese and transfer at the cheese rind interface was validated on an old ripened high salted cheese (namely "old cheese") with no salt gradient and without $\mathrm{CO}_{2}$ production (no $\mathrm{CO}_{2}$ producing bacteria). The cheese was high salted via brining (about $5 \% \mathrm{NaCl} / \mathrm{dm}$, salt content on dry matter) in order to avoid possible gas production from unwanted microorganisms in such old cheese. The cheese, apart for its upper rind, was fully covered with a gas impermeable membrane (see Supplementary Material A) and it was housed in a controlled temperature cabinet (set at $19^{\circ} \mathrm{C}$ ) with a continuous flow of wet $\mathrm{CO}_{2}$ (gas supposed to be equilibrated at $100 \%$ of relative humidity after bubbling in a flask containing pure water at the temperature of the experiment). After 3 days, the $\mathrm{CO}_{2}$ dissolved in different positions (e.g. the sample is sliced parallel to the interface) from the upper rind $(x=0)$ to the 


\section{Journal of Food Engineering}

275 bottom rind $(\mathrm{x}=8)$ was assessed with the $\mathrm{CO}_{2}$ determination method described above. Two

276 repetitions were made in order to validate the diffusion phenomenon. For two other repetitions,

277 after 3 days of $\mathrm{CO}_{2}$ sorption, the cheese samples were then kept 3 days in a continuous flow of

278 wet $(100 \% \mathrm{RH}) \mathrm{N}_{2}$ (desorption step). The gradient of dissolved $\mathrm{CO}_{2}$ into the paste after these 3

279 days of desorption was then assayed as previously described for the sorption step (2 repetitions).

2802 Secondly the coupling of $\mathrm{CO}_{2}$ diffusion and production was experimentally assessed by using

281 a cheese with $\mathrm{PAB}$ and average salt concentration (about $2.5 \% \mathrm{NaCl} / \mathrm{dm}$, salt on dry matter, in

282 the cheese, namely "young cheese"). This cheese also included a salt gradient due to its younger

283 age (15 days from renneting) when salt is still slowly diffusing from rind to core of the cheese

284 (brined cheese). The same experimental procedure previously described was used, apart for the

285 following: the cheese stayed 1 day at $19^{\circ} \mathrm{C}$, before the experiment with the contact of wet $\mathrm{CO}_{2}$

286 from upper rind $(\mathrm{x}=0)$ started and it lasted for 4.4 days.

287 The initial $\mathrm{CO}_{2}$ concentration gradient in the cheese was measured just before the experiment

288 started (i.e. about 9.5 weeks from renneting for the first validation step and 15 days from

289 renneting for the second more complex validation step including $\mathrm{CO}_{2}$ production). This initial

$290 \mathrm{CO}_{2}$ gradient is indispensable to parametrize initial conditions in the numerical algorithm.

2913 Thirdly, in order to compare the output of gas concentration in the headspace given by the

292 model including permeation phenomenon, gas headspace composition was measured in the

293 headspace of packed cheeses (2 replications). The headspace gas analyses were repeated on

294 different cheeses during ripening (about at $10,14,16$ ripening days at $19^{\circ} \mathrm{C}$ ).

296 In each case of these aforementioned steps, the model was adapted accordingly to experimental

297 conditions: system of Eq. (6) to (15) for the first and second steps - without the production term

298 in Eq. (9) and related Eq. (13) - and system of Eq. (1) to Eq. (18) for the third, full case. 
Journal of Food Engineering

\subsection{Statistics}

301 Statistical tests were performed by using R software for statistical computing (R, 2014).

302 Comparisons between the chemical compositions were performed by pairwise comparisons using $303 t$ test with pooled standard deviation. The Holm method for the multiplicity of error was used to 304 adjust the p-value of multiple pairwise comparisons. Different letters were used for denoting 305 significant difference between data sets (level of significance $\alpha=0.05$, unless stated).

\section{3. Results and discussion}

308 Our model takes into account experimentally assessed parameters for describing $\mathrm{CO}_{2}$ production 309 and overall transfer in and out a cheese/packaging system during foil ripening. The focus was on 310 the exhaustive description of the gas transport properties in the continuous cheese paste and at its 311 interface with the surrounding atmosphere. We therefore used a model blind cheese (without 312 eyes). We experimentally assessed the following parameters: transport of $\mathrm{CO}_{2}$ in the cheese paste 313 (effective diffusivity), transfer of $\mathrm{CO}_{2}$ at the interface between cheese and headspace (solubility), 314 oxygen, nitrogen and carbon dioxide transmission rate through the maturation foil (permeability) 315 and $\mathrm{CO}_{2}$ production rate from the bacteria. The cited parameters were previously assessed in 316 function of the main ripening variables (different temperatures, ripening time, salt content 317 amongst others) (Acerbi et al., 2016a, 2016b, 2016c, 2016d).

320 The chemical composition of the cheese without PAB (old cheese - data not shown) was not 321 significantly different $(\alpha=0.05)$ as a function of the position in the cheese, whereas a relevant 322 gradient in PTATN (ratio of phosphotungstic acid soluble nitrogen on total nitrogen) and SM 
Journal of Food Engineering

323 (salt in moisture ratio) was confirmed from analyses made on cheese with PAB analysed at 15 324 and 20 days from renneting (figure 3).

325 Although the transfer properties of nitrogen components (PTATN) and salt were not

326

327

328

\section{Figure 3}

A relevant gradient in organic acid concentration was found in the cheese with PAB both at 15 and 20 days from renneting (figure 4). No propionate and acetate was found in the outer rind (0 $\mathrm{cm})$ at 15 days from renneting. The observed delay in PAB fermentation in the outer part of the cheese was probably due to the negative effect of high salt to moisture ratio on the bacteria cells (Guinee, 2004) and it was already demonstrated by Huc et al. (2014) in similar cheeses. The molar ratio between propionate and acetate in the core of the cheese equalled about 2 . The ratio of 2 is obtained if PAB convert lactate exclusively via the Fitz pathway (Fröhlich-Wyder and Bachmann, 2004; Piveteau, 1999; Fedio et al., 1994). We can therefore confirm that, in the studied cheese, PAB fermented lactate primarily via the Fitz pathway and that probably no other metabolic activity (producing acetate) occurred.

\section{Figure 4}


Journal of Food Engineering

346 The $\mathrm{pH}$ of the cheese was measured because $\mathrm{pH}$ changes may affect both the solubility of carbon

347 dioxide dissolved in the water phase of the cheese (Chaix et al., 2014) and its diffusivity

348 coefficient due to a different organisation of the casein matrix structure (Lawrence et al., 1987).

349 The $\mathrm{pH}$ in the studied cheese did not relevantly vary in the considered experimental time (figure $350 \quad 5 a)$

351 The enumeration of PAB cells confirmed the higher metabolic activity observed in the core of the 352 cheese (figure 5b).

\subsection{Initial $\mathrm{CO}_{2}$ concentration}

The initial $\mathrm{CO}_{2}$ concentration in different positions (from upper to bottom rind) of the cheese was measured in 2 to 3 cheeses produced within the same production batch. Whereas the $\mathrm{CO}_{2}$ distribution was low and rather homogeneous for the old ripened cheese with no intentionally added $\mathrm{CO}_{2}$ producing bacteria (figure $6 \mathrm{a}, 3$ repetitions), the initial $\mathrm{CO}_{2}$ gradient was relevant in the cheese with $\mathrm{PAB}$ (figure $6 \mathrm{~b}, 2$ repetitions). The low and homogeneous initial $\mathrm{CO}_{2}$ concentration observed in the older cheese was expected because this cheese did not contain intentionally added $\mathrm{CO}_{2}$ producing bacteria, while the $\mathrm{CO}_{2}$ gradient observed in the cheese with $\mathrm{PAB}$ at 15 days from renneting $\left(14\right.$ days at $13^{\circ} \mathrm{C}$ and 1 days at $\left.19^{\circ} \mathrm{C}\right)$ reflected the effect of salt gradient on PAB. There is an inhibition of PAB growth (Figure 5b) by the higher salt content close to the rinds with a consequently lower production of $\mathrm{CO}_{2}$ and propionic acid close to the rinds compare to the core of the product leading to this "bell like curve" for initial $\mathrm{CO}_{2}$ gradient in salted cheese with PAB. This evolution of salt content that is spatially-dependant, due to diffusion of salt from the periphery towards the centre of cheeses, has been found in previous 
Journal of Food Engineering

370

371

372

373

374

375

376

377

378

379

380

381

382

383

384

385

386

387

388

389

390

391

392

studies (Huc et al., 2014; Guinee, 2004; Hollywood \& Doelle, 1984) and before by Mocquot (1979), Geurts et al. (1974, 1980) and Pauchard et al. (1980). Therefore, the median value for initial $\mathrm{CO}_{2}$ concentration was used $(4 \mathrm{mmol} / \mathrm{kg})$ for the model validated for the cheese without $\mathrm{PAB}$ and the real gradient was used as input vector for initial $\mathrm{CO}_{2}$ concentration for the cheese with PAB.

\subsection{Investigating effect of salt content on $\mathrm{CO} 2$ solubility}

Prior model validation, additional points of solubility of $\mathrm{CO}_{2}$ within the cheese paste were measured to complete the work of Acerbi et al. (2016b) and obtain more precise $S_{C O 2}$ prediction (eq. 15). According to these new values (Figure 2), $S_{\mathrm{CO}_{2}}$ increased with light $\mathrm{NaCl}$ content, while it decreased at very high $\mathrm{NaCl}$ content, following a similar behaviour compared to salting in and salting out effect of protein. This phenomenon was ascribed to the possibly higher sorption of $\mathrm{CO}_{2}$ in highly hydrated protein during salting in phase (Guinee, 2004), while the overall $S_{\mathrm{CO} 2}$ would decrease due to lower level of protein hydration at high salt concentration (salting out). Guinee (2004) suggested that salting out effect of protein in cheese (Mozzarella) may take place for salt to moisture ratio $(\mathrm{S} / \mathrm{M})$ higher than $6.3 \% \mathrm{w} / \mathrm{w}$, which is close to the highest salt level investigated in Figure 2 (about 6.7\% S/M).

\subsection{Model validation}

The simplest model form describing $\mathrm{CO}_{2}$ diffusion inside the cheese paste (without $\mathrm{PAB}$ and $\mathrm{CO}_{2}$ production) and the transfer at the cheese rind/gaseous interface $\left(100 \% \mathrm{CO}_{2}\right)$ was successfully validated because the difference between predicted and experimental data was below $10 \%$ (figure 
Journal of Food Engineering

393 7a). Same good validation with a $100 \% \mathrm{~N}_{2}$ flux at the cheese rind surface was obtained 394 (CVRMSD < 8\%) (see Supplementary Material B).

395 When increasing the complexity of the model, including $\mathrm{CO}_{2}$ production rate and considering a 396 cheese with salt gradient, the observed error between experimental and predicted data was found 397 higher (30\%) (figure $7 \mathrm{~b}$ ). In the latter more complex model, the predicted line was generally 398 underestimating the experimental gradient, leading to a high CVRMSD. The lack of fit of the 399 more complex model could be due to (1) the adoption of a mono-directional model which may 400 not be fully appropriate for diffusion in cheeses with gas production and/or (2) underestimations 401 in either the prediction of $\mathrm{CO}_{2}$ production rate and/or in the initial $\mathrm{CO}_{2}$ concentration gradient. 402 Underestimation of the $\mathrm{CO}_{2}$ production rate may be due to the linear approximation used by 403 Acerbi et al. (2016a) to describe the effect of salt content. Indeed, lower salt contents were 404 investigated in the previous work, which provided the predictive equation for $\mathrm{CO}_{2}$ production 405 rate, compared to the current study. Therefore, effect of high SM ratio is probably not well 406 predicted by Eq.13 which was never validated for such SM ratio. This underestimation may be 407 overcome by carrying out more experimental measurements of $\mathrm{CO}_{2}$ production rate at higher salt content. A possible underestimation of the initial $\mathrm{CO}_{2}$ concentration gradient in the cheese may be ascribed to natural deviations in metabolic activity of the PAB in different cheeses produced from the same batch. Both hypotheses were confirmed by simulating a 1.7 folds higher $\mathrm{CO}_{2}$ production rate (figure 8) and then, a 2 folds higher initial $\mathrm{CO}_{2}$ concentration (figure 9). In both cases, the predicted curve fit very well the experimental data. 
420 Then, the full model considering permeation through ripening foil in addition to

421 solubilisation/diffusion and production of $\mathrm{CO}_{2}$ within the food was then used to predict the $\mathrm{CO}_{2}$

422 partial pressure in headspace. A third set of experiments conducted on cheeses packed in ripening

423 foils were conducted in the objective to validate it. Experimental difficulties arose because gas

424 headspace analysis could not be assessed continuously in the pack (because of too high gas

425 volume injected) therefore only a few experimental points have been collected (See

426 supplementary material C). However, it has been noted that the model tended to underestimate

427 the headspace partial pressure when $\mathrm{CO}_{2}$ production occurs (in cheese with $\mathrm{PAB}$ ). But, once

428 again, considering a 1.7 fold higher $\mathrm{CO}_{2}$ production rate, the prediction fitted better the

429 experimental data. A better fit may also be obtained by reducing the value for $\mathrm{CO}_{2}$ permeability

430 of the packaging or increasing the initial $\mathrm{CO}_{2}$ concentration gradient (results not shown). But this

431 hypothesis does not sound well founded and therefore was not applied. The permeability values

432 were especially assessed in the conditions encountered in the present work and were therefore

433 considered relevant.

$434 \quad 3.5$ Exploratory analysis of model simulations

435 Simulations were carried by considering the min and max values of 4 parameters in their range of

436 variation (table 2): $\mathrm{CO}_{2}$ solubility (figure 10a), diffusivity (figure 10b), permeability (figure 10c)

437 and production coefficients (figure 10d). During the simulation, only one of the mentioned input

438 parameters was varied from the lowest to the highest value described in Table 2. The boundary 


\section{Journal of Food Engineering}

439 conditions used during these simulations included that the packed cheese was in contact with the

440 atmosphere $\left(20.9 \% \mathrm{O}_{2}, 0.03 \% \mathrm{CO}_{2}, 78.1 \% \mathrm{~N}_{2}\right)$ from one rind (upper rind) and in contact with a 441 non-permeable support from the below rind (shelf). The range of values for solubility and 442 diffusivity was chosen in agreement with the min and max observed in the experimental 443 campaign described by Acerbi et al. (2016b, 2016d). The values for permeability were decided to

444

445

446

447

448

449

450

451

452

453

454

455

456

457

458

459

460

461 vary of factor 10 of the predicted value of Equation 16, 17, 18. The value of production rate was decided to vary of 4 units compared to the predicted value of equation 13 , because it was considered a realistic variation for the different salt contents observed in different positions of the studied cheese at $19^{\circ} \mathrm{C}$.

The other input parameters were kept fixed (medium value) as respect of their position. This simplified sensitivity analysis had the goal of highlighting which input parameter had the strongest effect on the output $\left(\mathrm{CO}_{2}\right.$ gradients formed in cheese). Logically, changing $\mathrm{S}_{\mathrm{CO} 2}$ led to light differences in $\mathrm{CO}_{2}$ concentration only close to the gaseous interface (figure 10a) because this parameter only intervenes in the boundary condition at cheese/headspace interface: the lower the solubility, the lower the $\mathrm{CO}_{2}$ content at the interface. Changing $\mathrm{D}_{\mathrm{CO} 2}$ slightly affected the shape of the $\mathrm{CO}_{2}$ gradient close to the cheese rinds, probably because these positions were characterized by lower $v_{\mathrm{CO} 2}$ due to the higher salt content (figure 10b) and it affected the overall shape of the curve. $v_{\mathrm{CO} 2}$ showed the highest effect on the $\mathrm{CO}_{2}$ gradients, from -10 to +20 $\mathrm{mmol} / \mathrm{kg}$ of difference for the lowest and highest $v_{\mathrm{CO} 2}$ respectively compared to the median value in the core of the cheese. Concerning the effect of different permeability, the lower the gas 


\section{ACCEPTED MANUSCRIPT}

\section{Journal of Food Engineering}

462

463

464

465

466

467

468

469

470

471

472

473

474

475

476

477

478

479

480

481

482

483

484

485

permeability of the packaging, the higher was the $\mathrm{CO}_{2}$ concentration at the cheese rind, but the overall change in $\mathrm{CO}_{2}$ gradient due to different permeability was negligible.

\section{Figure 10}

This paper presents an unprecedented modelling approach that successfully describes the mechanisms of $\mathrm{CO}_{2}$ diffusion, solubilisation and production by Swiss-type cheese with intensive PAB-based $\mathrm{CO}_{2}$ production and also $\mathrm{CO}_{2}$ permeation through the ripening foil. All mechanisms were dynamically coupled and experimentally validated permitting to achieve the initial objective of this paper which was to predict evolution with time of $\mathrm{CO}_{2}$ gradients into the packed cheese. The developed model is the most complete one compare to precedent similar approach of the literature. For instance, the one of Jakobsen and Risbo, (2009), developed for prediction, among others, of the changes in solubilised carbon dioxide in semi-hard cheese packed in modified atmosphere packaging, neglected all mechanisms of $\mathrm{CO}_{2}$ diffusion and production in their approach.

This model could be further used to predict $\mathrm{CO}_{2}$ gradients into blind cheese or, once coupled with a mechanical model of bubble growth such as the one proposed by Laridon et al., (2014), could be used to predict eye growth in Swiss type cheese and then pilot the ripening step.

\section{Conclusion}

We presented the first experimentally validated model which couples the phenomena of $\mathrm{CO}_{2}$ production, solubilisation/diffusion and permeation in a packed cheese system for predicting the $\mathrm{CO}_{2}$ gradients formed in the cheese during ripening. A three steps validation procedure enabled to build a robust model for a quantitative description of $\mathrm{CO}_{2}$ gradient formed in a cheese with or 


\section{ACCEPTED MANUSCRIPT}

Journal of Food Engineering

486

487

488

489

490

491

492

493

494 without $\mathrm{CO}_{2}$ production by $\mathrm{PAB}$ and including the phenomena of $\mathrm{CO}_{2}$ diffusion in the cheese paste and transfer at the gaseous interface. The model was able to describe the shape of the $\mathrm{CO}_{2}$ gradient formed in the cheese with, nevertheless, less precision when $\mathrm{CO}_{2}$ production happens.

This term was probably less accurately characterized for the conditions used in this paper and induces less performant prediction. A simplified sensitivity analysis highlighted $\mathrm{CO}_{2}$ production as the most important input parameter affecting the $\mathrm{CO}_{2}$ gradients formed in cheese during ripening. Results presented in this paper represent a solid basis for the description of the most important phenomena affecting the quality of cheese with intense $\mathrm{CO}_{2}$ production during ripening. 


\section{ACCEPTED MANUSCRIPT}

\section{Journal of Food Engineering}

495

496

497

498

499

500

501

502

503

504

505

506

507

508

509

510

511

512

513

514

515

516

517

518

\section{References}

Anonymous 2004a. ISO 5534. Cheese and processed cheese -- Determination of the total solids content (Reference method). International Organization for Standardization, Geneva

Anonymous 2004b. ISO 8968-3. Milk -- Determination of nitrogen content -- Part 3: Block-digestion method (Semi-micro rapid routine method). International Organization for Standardization, Geneva

Anonymous 2006. ISO 5943. Cheese and processed cheese products -- Determination of chloride content -- Potentiometric titration method. International Organization for Standardization, Geneva

Anonymous 2009. FD V04-035. Lait et produits laitiers - Détermination du pH. Afnor, France

Anonymous 2002. NF V04-287. Fromages - Détermination de la teneur en matière grasse - Méthode acido-butyrométrique, Afnor, France

Acerbi, F., Guillard, V., Aliani, M., Guillaume, C., Gontard, N., 2016a. Impact of salt concentration, ripening temperature and ripening time on $\mathrm{CO} 2$ production of semi-hard cheese with propionic acid fermentation. J. Food Eng. 177, 7279. doi:http://dx.doi.org/10/2016/j/jfoodeng.2015.12.022

Acerbi, F., Guillard, V., Guillaume, C., Gontard, N., 2016b. Impact of selected composition and ripening conditions on CO2 solubility in semi-hard cheese. Food Chem. 192, 805-812. doi:10.1016/j.foodchem.2015.07.049

Acerbi, F., Guillard, V., Guillaume, C., Gontard, N., 2016c. Assessment of gas permeability of the whole packaging system mimicking industrial conditions. Food Packag. Shelf Life 8, 81-85. doi:https://doi.org/10.1016/j.fpsl.2016.04.003

Acerbi, F., Guillard, V., Guillaume, C., Saubanere, M., Gontard, N., 2016d. An appraisal of the impact of compositional and ripening parameters on $\mathrm{CO} 2$ diffusivity in semi-hard cheese. Food Chem. 194, 1172-1179. doi:10.1016/j.foodchem.2015.08.020

Bacigalupi, C., Lemaistre, Marie Hélène Peyron, S., Guillard, V., Chalier, P., 2013. Changes in nutritional and sensory properties of orange juice packed in PET bottles: an experimental and modelling 


\section{ACCEPTED MANUSCRIPT}

\section{Journal of Food Engineering}

approach. Food Chem. 141, 3827-3836.

Bona, E., Silva, R. S. S. F. d., Borsato, D., Silva, L. H. M., \& Fidelis, D. A. d. S. (2007). Multicomponent diffusion modeling and simulation in prato cheese salting using brine at rest: The finite element method approach. Journal of Food Engineering, 79(3), 771-778. doi:10.1016/j.jfoodeng.2006.02.041

Bütikofer, U., Ruegg, M., Ardo, Y., 1993. Determination of nitrogen fractions in cheese: evaluation of a collaborative study. Food Sci. Technol. - Leb. - Wiss. Technol. doi:10.1006/fstl.1993.1056

Chaix, E., Couvert, O., Guillaume, C., Gontard, N., \& Guillard, V. (2015). Predictive Microbiology Coupled with Gas (02/CO2) Transfer in Food/Packaging Systems: How to Develop an Efficient Decision Support Tool for Food Packaging Dimensioning. Comprehensive Reviews in Food Science and Food Safety, 14(1), 1-21. doi:10.1111/1541-4337.12117

Chaix, E., Guillaume, C., \& Guillard, V. (2014). Oxygen and Carbon Dioxide Solubility and Diffusivity in Solid Food Matrices: A Review of Past and Current Knowledge. Comprehensive Reviews in Food Science and Food Safety, 13(3), 261-286. doi:10.1111/1541-4337.12058

Dean, J. A. (1999). Physical Properties. Solubilities of gases in water. In J. A. Dean (Ed.), Lange's Handbook of Chemistry (15 ed., pp. 375-380): McGraw-Hill Inc.

Fedio WM, Ozimek L, Wolfe FH. 1994. Gas production during the storage of Swiss cheese. Milchwissenschaft-Milk Science International 49(1):3-8.

Fick, A., 1855. On liquid diffusion. J. Memb. Sci. 100, 33-38.

Fröhlich-Wyder MT, Bachmann HP. 2004. Cheeses with propionic acid fermentation. In: Fox PF, McSweeney PLH, Cogan TM, Guinee TP, editors. Cheese: Chemistry, Physics and Microbiology. 3 ed. London: Elsevier Academic Press. p. 141-156.

Geurts, T. J., Walstra, P., \& Mulder, H. (1974). Transport of salt and water during salting of cheese. 1. Analysis of the processes involved. Netherlands Milk and Dairy Journal, 28,102-129. 


\section{ACCEPTED MANUSCRIPT}

Journal of Food Engineering

Geurts, T. J., Walstra, P., \& Mulder, H. (1980). Transport of salt and water during salting of cheese. 2. Quantities of salt taken up of moisture lost. Netherlands Milk and Dairy Journal, 34, 229-254.

Guillard, V., Guillaume, C., Destercke, S., 2012. Parameter uncertainties and error propagation in modified atmosphere packaging modelling. Postharvest Biol. Technol. 67, 154-166. doi:10.1016/j.postharvbio.2011.12.014

Guinee, T. P. (2004). Salting and the role of salt in cheese. International Journal of Dairy Technology, 57(2-3), 99-109.

Ho, Q. T., Verboven, P., Verlinden, B. E., Herremans, E., Wevers, M., Carmeliet, J., \& Nicolaï, B. M. (2011). A Three-Dimensional Multiscale Model for Gas Exchange in Fruit. Plant Physiology, 155(3), 11581168.

Hollywood, N.W., \& Doelle, H.W. (1984). The effect of sampling position and age on levels of propionibacteria and flavor-related compounds in Swiss-type cheese. Australian Journal of Dairy Technology, 39,80-82.

Huc, D., Roland, N., Grenier, D., Challois, S., Michon, C., \& Mariette, F. (2014). Influence of salt content on eye growth in semi-hard cheeses studied using magnetic resonance imaging and $\mathrm{CO} 2$ production measurements. International Dairy Journal, 35(2), 157-165. doi:http://dx.doi.org/10.1016/j.idairyj.2013.11.010

Jakobsen, M. \& Risbo, J., (2009). Carbon dioxide equilibrium between product and gas phase of modified atmosphere packaging systems: Exemplified by semihard cheese. Journal of Food Engineering. $92,285-290$. 
Journal of Food Engineering

Laridon Y., Grenier D., Houeix D., Doursat C., Lucas T., \& Flick, D. (2016). Modelling of the growth of a single bubble in semi-hard cheese, with experimental verification and sensitivity analysis. Applied Mathematical Modelling, 40 (23-24), 1339-1351.

Laridon Y. (2014). Modelling and visualization of a bubble growth in an evolutive, heterogeneous medium. Mechanics [physics]. University of Rennes 1. English. NNT : 2014REN1S091

Lawrence R. C., Creamer, L. K., \& Gilles, J. (1987). Texture Development During Cheese Ripening. Journal of Dairy Science, 70(8), 1748-1760.

Mayor, L., \& Sereno, A. M. (2004). Modelling shrinkage during convective drying of food materials: a review. Journal of Food Engineering, 61(3), 373-386. doi:http://dx.doi.org/10.1016/S02608774(03)00144-4

Mocquot, B.Y.G., 1979. Reviews of the progress of Dairy Science : Swiss-type cheese. J. Dairy Res. 46, 133-160.

Payne, M. R., \& Morison, K. R. (1999). A multi-component approach to salt and water diffusion in cheese. International Dairy Journal, 9(12), 887-894. doi:http://dx.doi.org/10.1016/S09586946(99)00157-0

Pauchard, J.P., Flückiger, E., Bosset, J.O., Blanc, B., 1980. CO2 Löslichkeit, Konzentration bei Entstehung der Löcher und Verteilung in Emmentalerkäse. Schweizerische Milchwirtsch. Forsch. 9, 69-73.

Piveteau, P., (1999). Metabolism of lactate and sugars by dairy propionibacteria: A review. Lait 79, 2341.

R. (2014). R: A language and environment for statistical computing. Vienna, Austria. Retrieved from $<$ http://www.R-project.org/>.

Santapaola, J., Maldonado, S., \& Medina, J. L. (2013). NaCl diffusion kinetics in dry salting of goat cheese. Journal of Food Engineering, 118(2), 172-177.

doi:http://dx.doi.org/10.1016/j.jfoodeng.2013.03.028 
Journal of Food Engineering 
Figure 1: Scheme of the simplified food / packaging system with the four phenomena considered (mono-directional transfer through the headspace/cheese interface, $b r=$ cheese bottom-rind)

Figure 2. $\mathrm{CO}_{2}$ solubility in semi-hard Swiss-type cheese as a function of salt content at $13^{\circ} \mathrm{C}$. The point at intermediate $\mathrm{NaCl}$ content $(1.5 \% \mathrm{w} / \mathrm{w})$ is added to the ones reported by Acerbi et al. (2016b) and it was measured with same protocol on the same cheese. Different letters a, b c, ...denote significant difference for $\alpha=0.05$.

Figure 3. (a) PTATN - ratio of phosphotungstic acid soluble nitrogen on total nitrogen and (b) SM - salt in moisture ratio- in different positions of the of the semi-hard Swiss-type cheese with $\mathrm{PAB}$, from rind $(0 \mathrm{~cm})$ to core $(4 \mathrm{~cm})$ at 15 and 20 days from renneting, representing starting time and ending time of the validation experiment.

Figure 4. Propionate (a) and acetate (b) concentrations in different positions of the semi-hard Swiss-type cheese with PAB at 15 and 20 days from renneting (young cheese).

Figure 5. $\mathrm{pH}$ and $\mathrm{PAB}$ count in different positions of the semi-hard Swiss-type cheese with $\mathrm{PAB}$ at 15 and 20 days from renneting.

Figure 6. Median values for initial $\mathrm{CO}_{2}$ concentration measured in 9.5 weeks after renneting for old semi-hard Swiss-type cheese without PAB (a) and in 2 weeks after renneting for young semi-hard Swiss-type cheese with PAB (b). Horizontal and vertical error bars represent cheese position used and min and max values for assessed $\mathrm{CO}_{2}$ respectively.

Figure 7. Experimental (red dots) and predicted (solid line) $\mathrm{CO}_{2}$ concentration in the semihard cheese without $\mathrm{PAB}$ (a) and with $\mathrm{PAB}$ (b) $\mathrm{CO}_{2}$ production after about 4 ripening days at $19^{\circ} \mathrm{C}$. Root mean squared error (CVRMSD) is indicated on each figure. Error bars in experimental data represent standard deviations.

Figure 8. Predicted $\mathrm{CO}_{2}$ gradients in cheese (solid lines) after 1, 2, 3, 4 and 10 days of contact with $100 \% \mathrm{CO}_{2}$, calculated considering 1.7 folds higher $\mathrm{CO}_{2}$ production rate $\left(19^{\circ} \mathrm{C}\right)$. Red 
solid line and red error bars correspond to predicted and experimental $\mathrm{CO}_{2}$ gradient after 4 days of contact.

Figure 9. Predicted $\mathrm{CO}_{2}$ gradients in cheese (solid or dotted lines) after 1, 2, 3, 4 and 10 days of contact with $100 \% \mathrm{CO} 2$, calculated considering 2 folds higher initial $\mathrm{CO}_{2}$ gradient $\left(19^{\circ} \mathrm{C}\right)$. Red solid line and red error bars correspond to predicted and experimental $\mathrm{CO}_{2}$ gradient after 4 days of contact.

Figure 10. Effect of the intensity (low, medium and high, as stated in Table 2, in black, blue and red respectively) of the input parameter $\mathrm{CO}_{2}$ solubility (a), diffusivity (b) permeability (c) and production rate (d) on the predicted $\mathrm{CO}_{2}$ gradients in cheese ripened for 4 days at $19^{\circ} \mathrm{C}$ (age at beginning of ripening equalled 14 days from renneting). 
Table 1. Target chemical composition of "old" and "young" cheeses and steps of model validation

\begin{tabular}{|c|c|c|c|c|c|c|c|}
\hline $\begin{array}{l}\text { Type of } \\
\text { cheese }\end{array}$ & $\begin{array}{c}\text { Time } \\
\text { after } \\
\text { renneting }\end{array}$ & $\begin{array}{c}\text { Target } \\
\text { moisture } \% \\
\text { w/w }\end{array}$ & $\begin{array}{c}\text { Target fat } \\
\text { absolute \% } \\
\text { d.m. }\end{array}$ & $\begin{array}{l}\text { Target salt } \\
\text { content } \% \\
\mathrm{NaCl} / \mathrm{d} . \mathrm{m} \text {. }\end{array}$ & $\begin{array}{l}\text { Target } \\
\mathrm{pH}\end{array}$ & PAB & Validation step \\
\hline $\begin{array}{l}\text { "Old } \\
\text { cheese" }\end{array}$ & 15 days & 42 & 40 & $5 \%$ & 5.45 & No & (1) $\mathrm{CO}_{2}$ diffusion only \\
\hline $\begin{array}{l}\text { "Young } \\
\text { cheese" }\end{array}$ & $\begin{array}{c}9.5 \\
\text { weeks }\end{array}$ & 42 & 8 & $2.5 \%$ & 5.45 & Yes* & $\begin{array}{l}2 \mathrm{CO}_{2} \text { diffusion }+ \\
\text { production by } \mathrm{PAB} \\
3 \mathrm{CO}_{2} \text { diffusion }+ \\
\text { production by } \mathrm{PAB}+ \\
\mathrm{CO}_{2} \text { permeation } \\
\text { through ripening foil }\end{array}$ \\
\hline
\end{tabular}

$* 10^{6} \mathrm{CFU} \mathrm{ml}{ }^{-1}$ milk 
Table 2. Range of values used in the simulations

\begin{tabular}{|l|c|c|c|}
\hline Parameter/level & low & medium & high \\
\hline Solubility $\left(\mathrm{mmol} \mathrm{kg}^{-1} \mathrm{~atm}^{-1}\right)$ & 25 & 36 & 40 \\
\hline Diffusivity $\left(10^{-10} \mathrm{~m}^{2} \mathrm{~s}^{-1}\right)$ & 1 & 4 & 8 \\
\hline Permeability $\left(\mathrm{cm}^{3} \mu \mathrm{m} \mathrm{m}^{-2} \mathrm{~d}^{-1} \mathrm{bar}^{-1}\right)$ & 4000 & 44000 & 440000 \\
\hline Production rate $\left(\mathrm{mmol} \mathrm{kg}^{-1} \mathrm{~d}^{-1}\right)$ & 2 & 4 & 8 \\
\hline
\end{tabular}


(atmosphere $\mathrm{CO}_{2}[0.03 \%]$ )

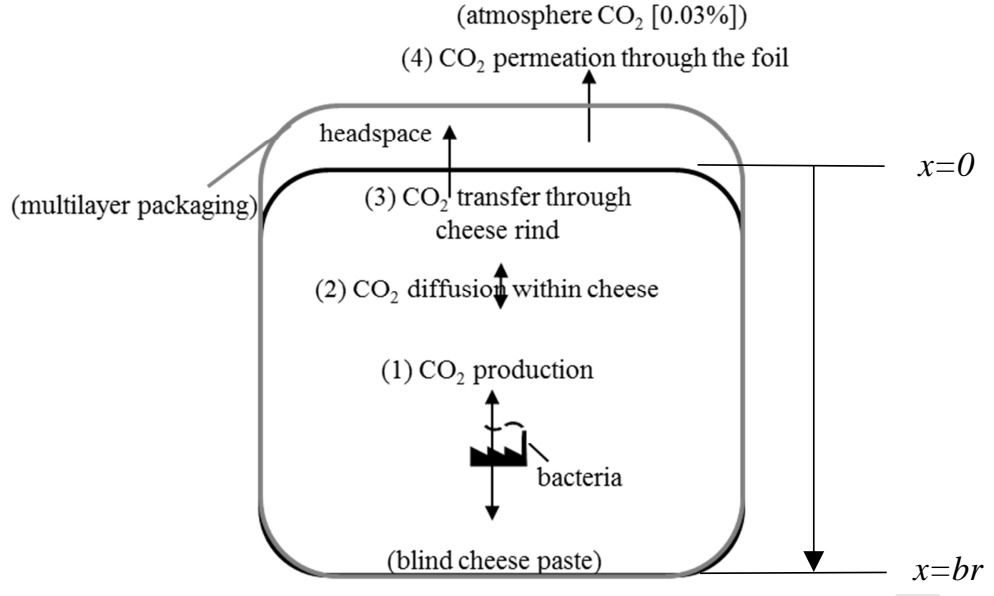

Figure 1: Scheme of the simplified food / packaging system with the four phenomena considered (mono-directional transfer through the headspace/cheese interface, $b r=$ cheese bottom-rind) 

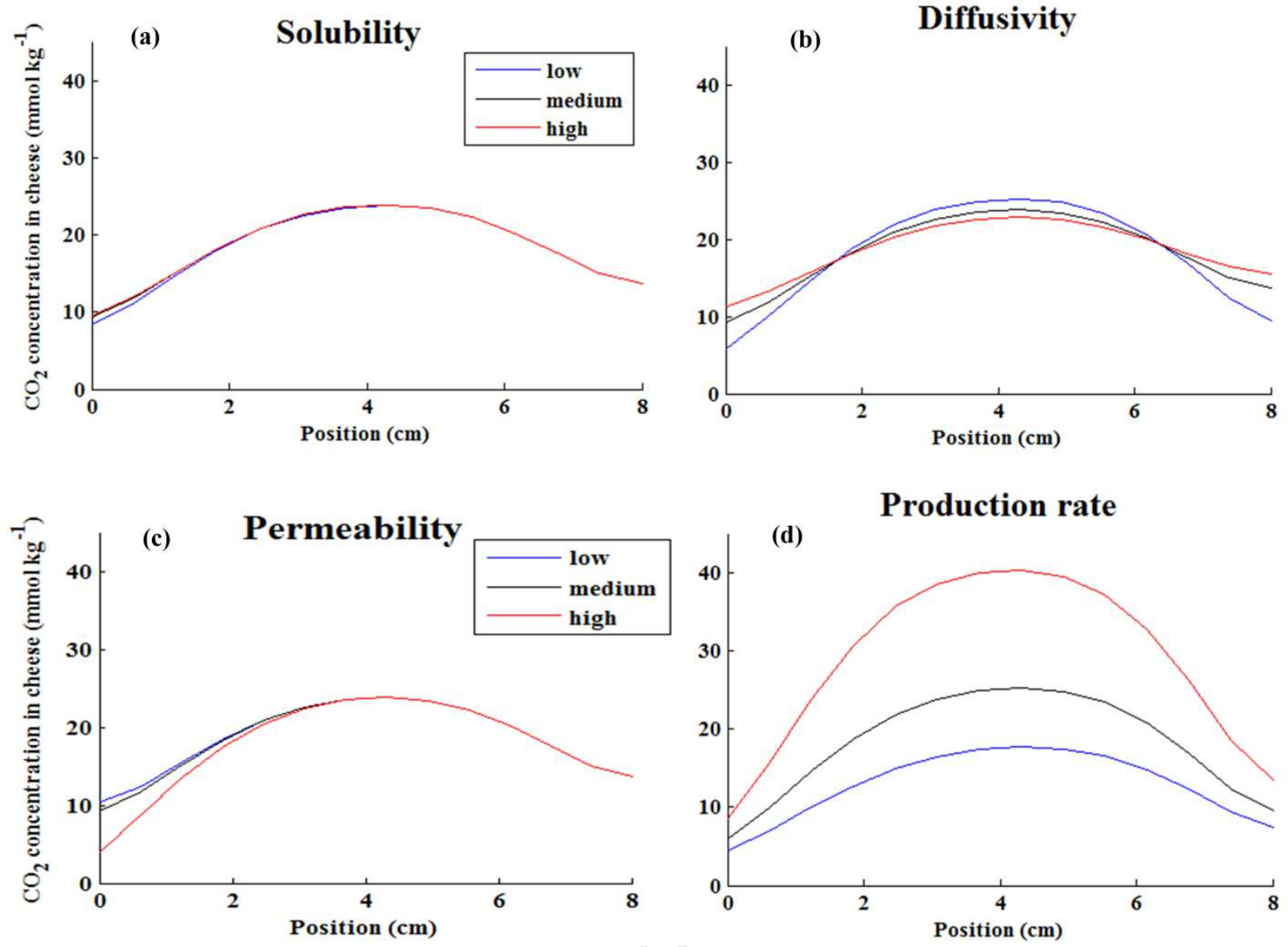

Figure 10. Effect of the intensity (low, medium and high, as stated in Table 2, in black, blue and red respectively) of the input parameter $\mathrm{CO}_{2}$ solubility (a), diffusivity (b) permeability (c) and production rate (d) on the predicted $\mathrm{CO}_{2}$ gradients in cheese ripened for 4 days at $19^{\circ} \mathrm{C}$ (age at beginning of ripening equalled 14 days from renneting). 


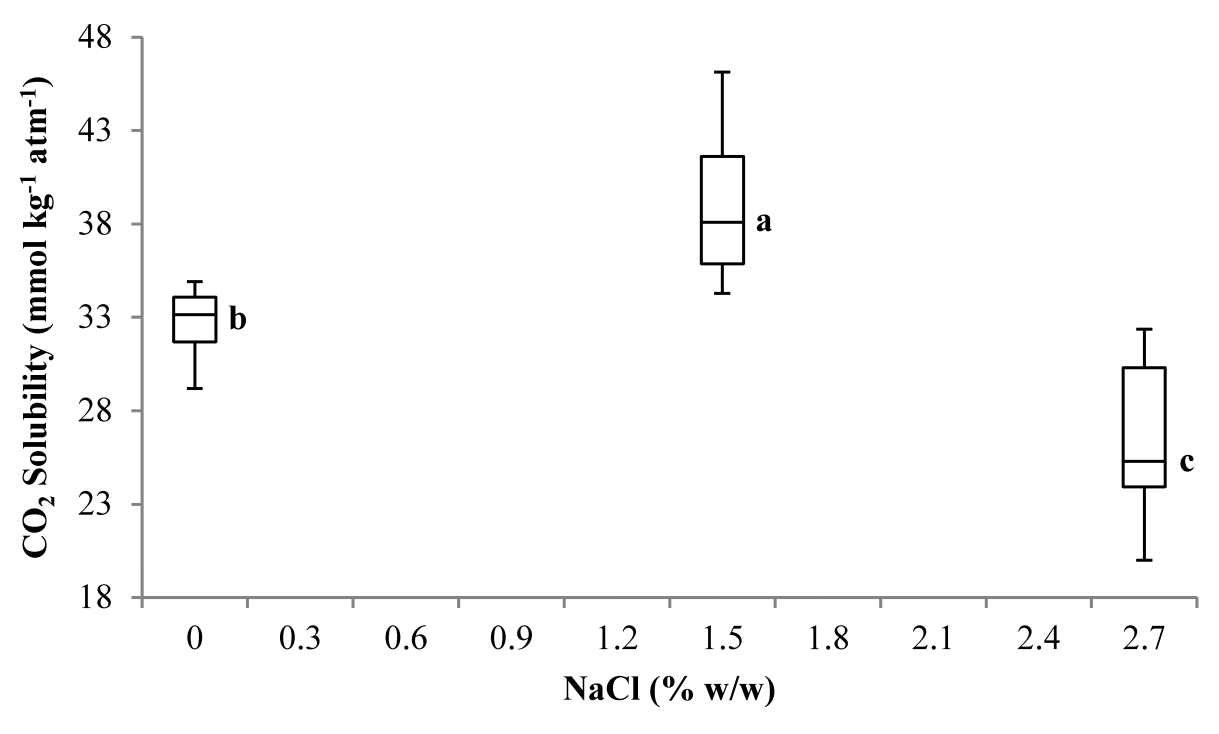

Figure 2. $\mathrm{CO}_{2}$ solubility in semi-hard Swiss-type cheese as a function of salt content at $13^{\circ} \mathrm{C}$. The point at intermediate $\mathrm{NaCl}$ content $(1.5 \% \mathrm{w} / \mathrm{w})$ is added to the ones reported by Acerbi et al. (2016b) and it was measured with same protocol on the same cheese. Different letters a, b c, ...denote significant difference for $\alpha=0.05$. 

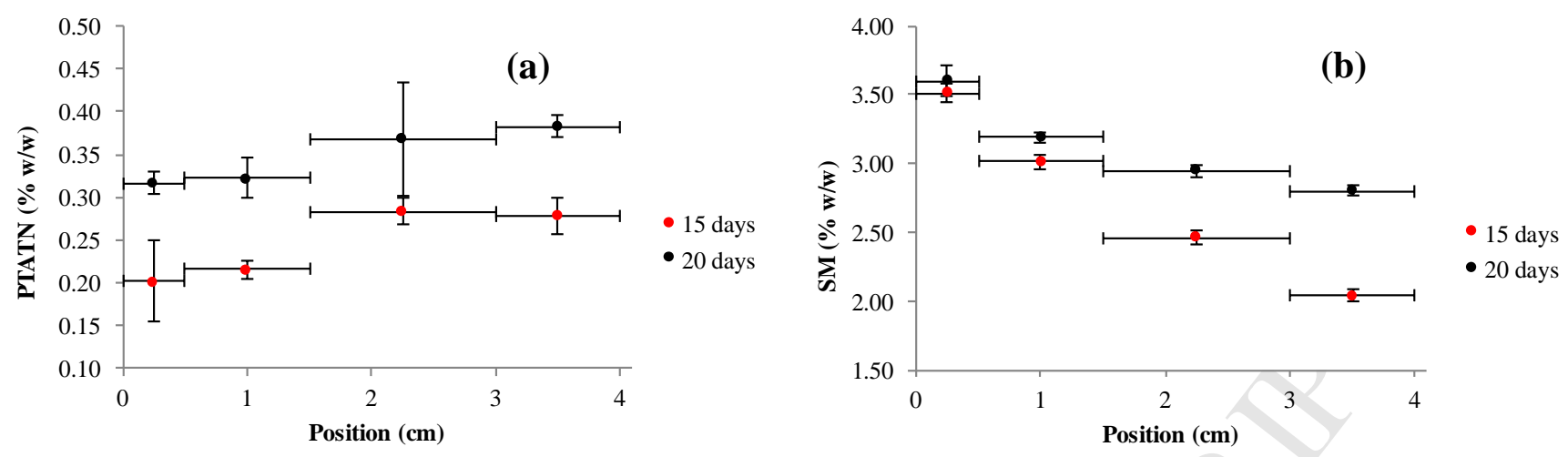

Figure 3. (a) PTATN - ratio of phosphotungstic acid soluble nitrogen on total nitrogen and (b) SM - salt in moisture ratio- in different positions of the of the semi-hard Swiss-type cheese with $\mathrm{PAB}$, from rind $(0 \mathrm{~cm})$ to core $(4 \mathrm{~cm})$ at 15 and 20 days from renneting, representing starting time and ending time of the validation experiment. 

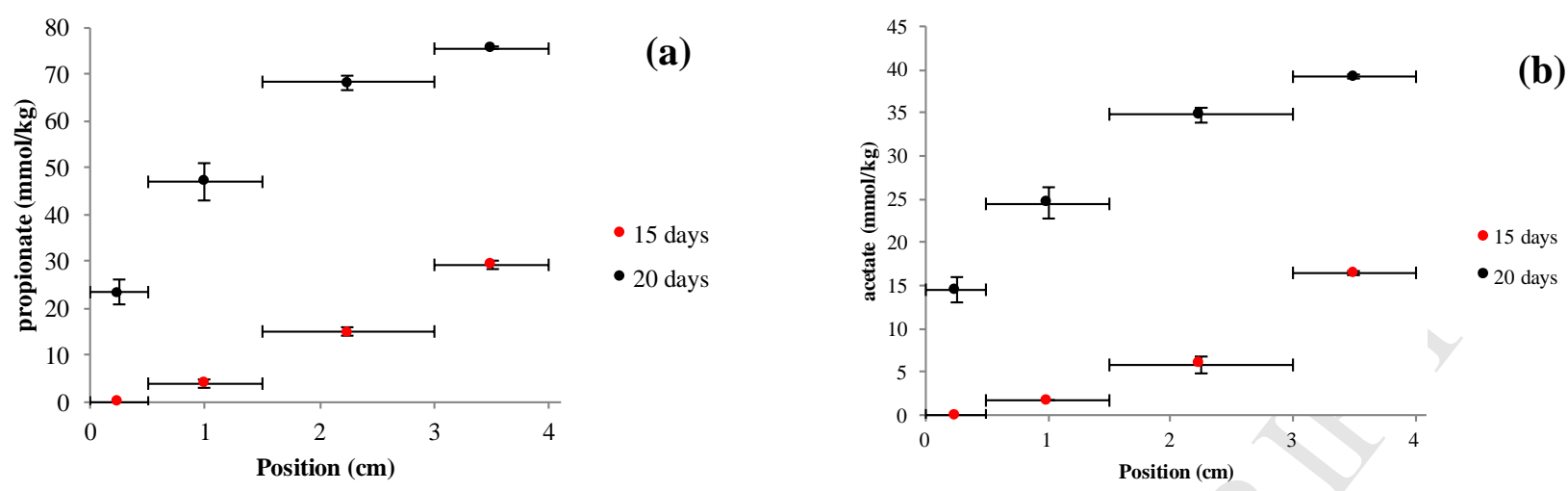

Figure 4. Propionate (a) and acetate (b) concentrations in different positions of the semi-hard Swiss-type cheese with PAB at 15 and 20 days from renneting (young cheese). 


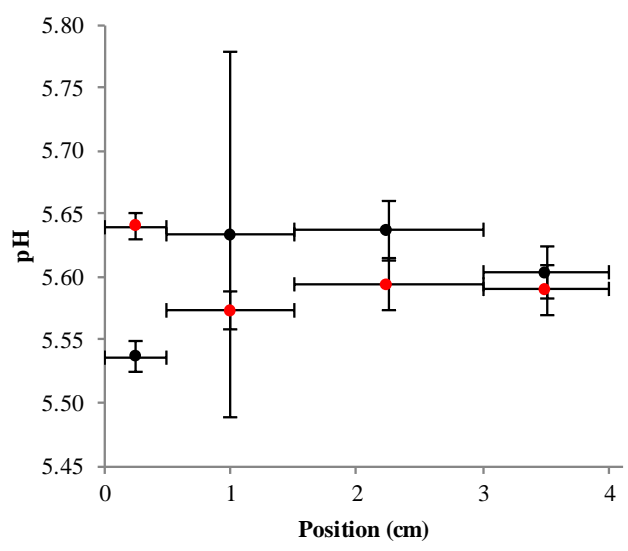

(a)

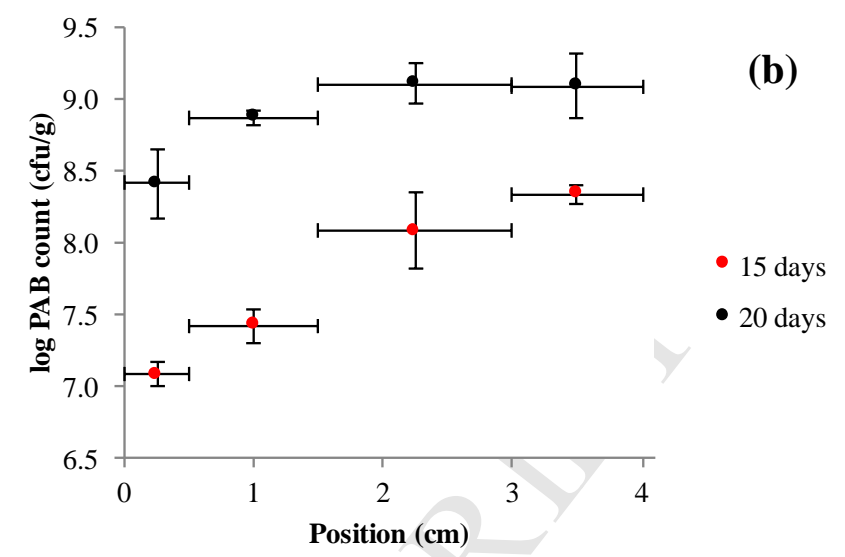

Figure 5. $\mathrm{pH}$ and PAB count in different positions of the semi-hard Swiss-type cheese with $\mathrm{PAB}$ at 15 and 20 days from renneting. 

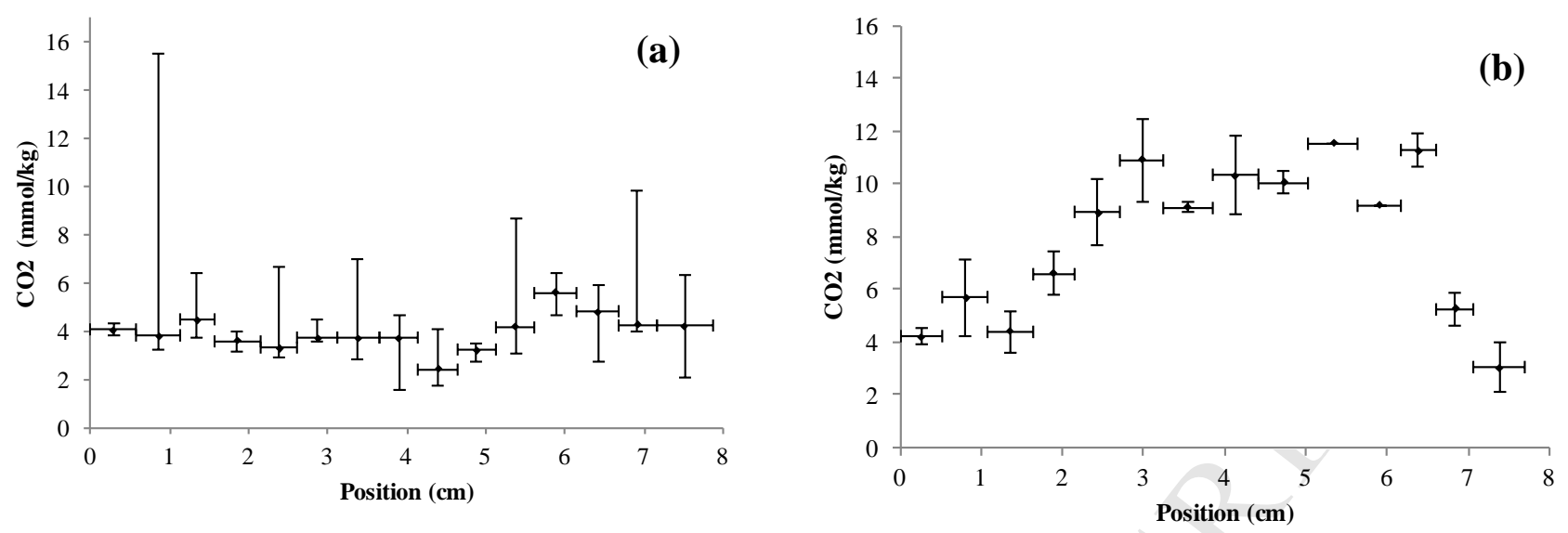

Figure 6. Median values for initial $\mathrm{CO}_{2}$ concentration measured in 9.5 weeks after renneting for old semi-hard Swiss-type cheese without PAB (a) and in 2 weeks after renneting for young semi-hard Swiss-type cheese with PAB (b). Horizontal and vertical error bars represent cheese position used and min and max values for assessed $\mathrm{CO}_{2}$ respectively. 

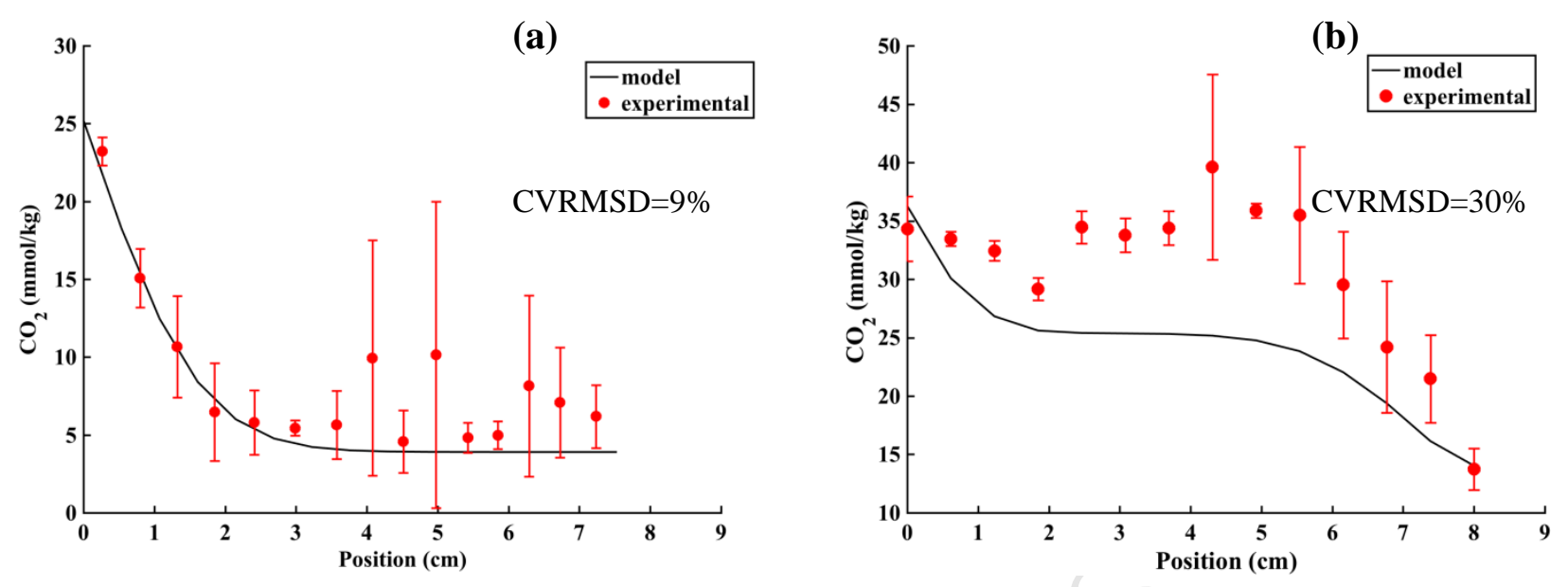

Figure 7. Experimental (red dots) and predicted (solid line) $\mathrm{CO}_{2}$ concentration in the semihard cheese without $\mathrm{PAB}$ (a) and with $\mathrm{PAB}$ (b) $\mathrm{CO}_{2}$ production after about 4 ripening days at $19^{\circ} \mathrm{C}$. Root mean squared error (CVRMSD) is indicated on each figure. Error bars in experimental data represent standard deviations. 


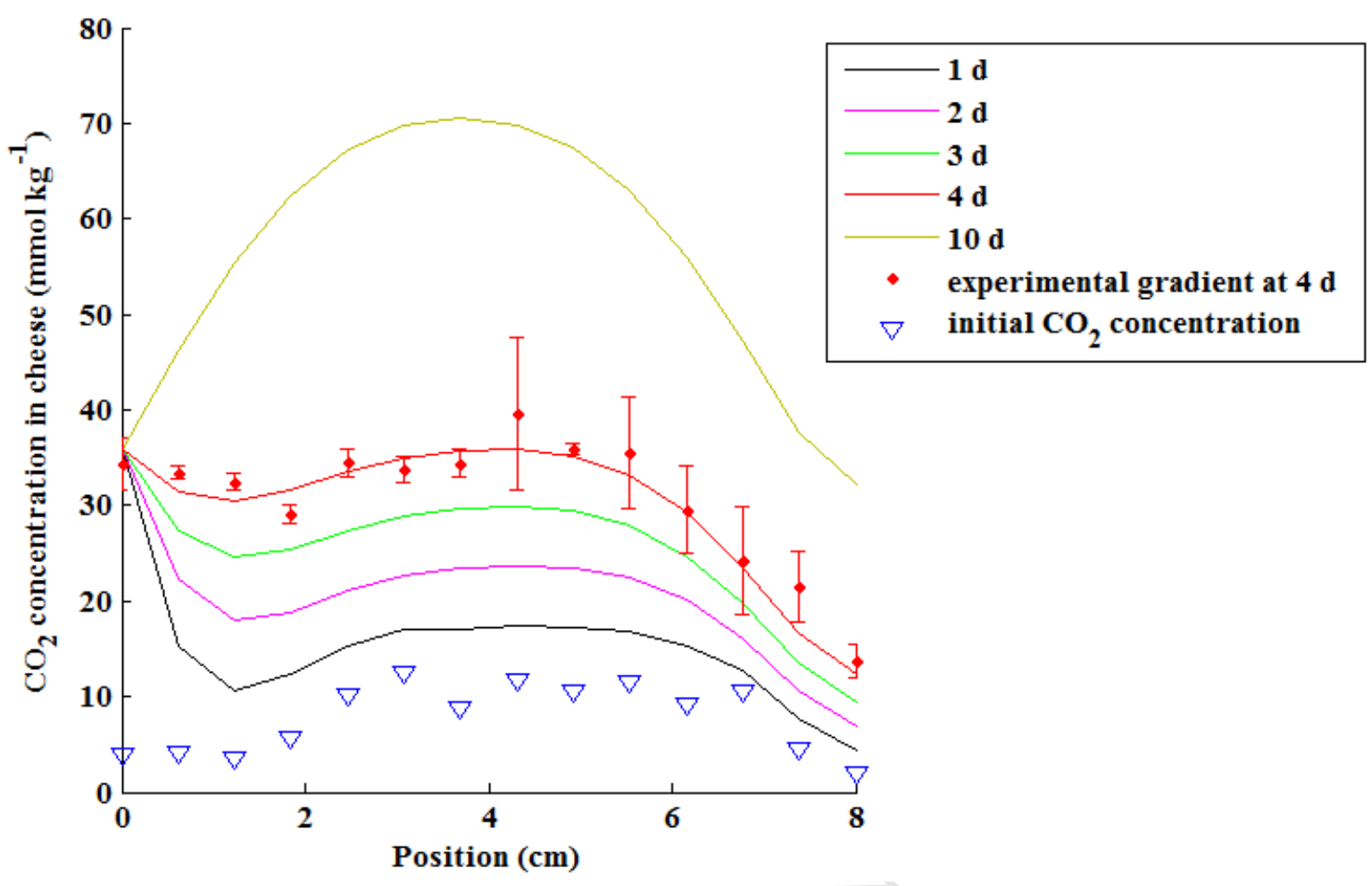

Figure 8. Predicted $\mathrm{CO}_{2}$ gradients in cheese (solid lines) after 1, 2, 3, 4 and 10 days of contact with $100 \% \mathrm{CO}_{2}$, calculated considering 1.7 folds higher $\mathrm{CO}_{2}$ production rate $\left(19^{\circ} \mathrm{C}\right)$. Red solid line and red error bars correspond to predicted and experimental $\mathrm{CO}_{2}$ gradient after 4 days of contact 


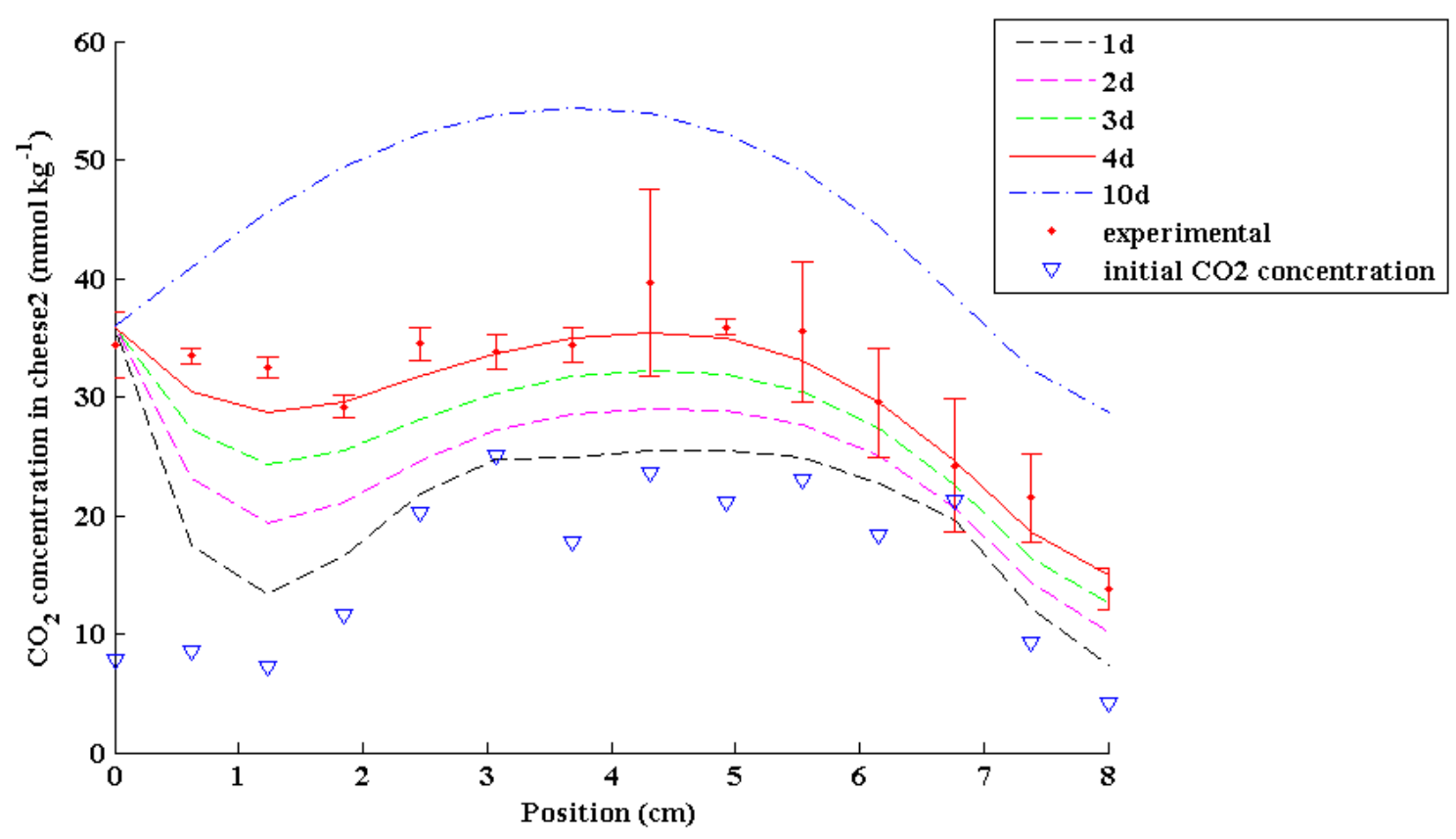

Figure 9. Predicted $\mathrm{CO}_{2}$ gradients in cheese (solid or dotted lines) after 1, 2, 3, 4 and 10 days of contact with $100 \% \mathrm{CO} 2$, calculated considering 2 folds higher initial $\mathrm{CO}_{2}$ gradient $\left(19^{\circ} \mathrm{C}\right)$. Red solid line and red error bars correspond to predicted and experimental $\mathrm{CO}_{2}$ gradient after 4 days of contact. 


\section{Highlights}

- We proposed the first validated model for the prediction of $\mathrm{CO}_{2}$ gradient in cheese.

- $\mathrm{CO}_{2}$ production is the most important parameter affecting $\mathrm{CO}_{2}$ gradients in cheese.

- A variation of a factor 10 of $\mathrm{CO}_{2}$ permeability of the packaging did not relevantly affect $\mathrm{CO}_{2}$ gradients in cheese

- $\mathrm{CO}_{2}$ permeability of the packaging did not relevantly affect $\mathrm{CO}_{2}$-gradients in cheese. 